\title{
Identification of a novel S6K1 splice variant coding for the p60-S6K1 isoform
}

\author{
I. V. Zaiets, V. V. Holiar, V. V. Filonenko \\ Institute of Molecular Biology and Genetics, NAS of Ukraine, \\ 150, Zabolotnogo str., 03680, Kyiv, Ukraine \\ filonenko@imbg.org.ua
}

\begin{abstract}
Aim. To identify a splicing mRNA of S6K1 kinase specific for the p60-S6K1 isoform alone. Methods. RT-PCR, DNA sequencing, Western blotting. Results. RT-PCR analysis of total RNA extracted from MCF-7 cells and subsequent DNA sequencing revealed a novel S6K1 splice variant that possesses additional exon 1a and encodes the p60 isoform of S6K1 only. Moreover, RT-PCR and western blotting were applied to estimate the expression levels of the p60-S6K1 mRNA and protein. A heterogeneous expression of the p60-S6K1 transcript was observed; it did not correlate with the total S6K1 mRNA expression and with the protein content of p60-S6K1 in the studied cell lines. Conclusions. We provide the evidence for the existence of a novel S6K1 splice variant coding for the p60-S6K1 isoform. The cell can employ two distinct pathways of the p60-S6K1 expression based on alternative translation of mRNA common for the main S6K1 isoforms mRNA and/or translation of the novel p60-S6K1 specific mRNA. Since the levels of the p60-S6K1 transcript expression do not correlate with the expression of total $\mathrm{S} 6 \mathrm{~K} 1 \mathrm{mRNA}$, it is plausible that the p60-S6K1 isoform plays a role distinct from that of other isoforms in cellular physiology, as well as in the development of S6K1related pathologies.
\end{abstract}

Keyw or d s: p60-S6K1 transcript, alternative splicing, gene expression

\section{Introduction}

The ribosomal protein S6 kinase 1 (S6K1, $R P S 6 K B 1$ gene) plays an important role in promoting fundamental cellular functions, including cell metabolism, growth and motility, and represents a downstream effector of the mTORC1 signaling pathway [1]. Indeed, the aberrant mTORC1 signaling underlies a number of path- ological conditions [2]. Numerous data indicate the implication of S6K1 in the development of human cancer. A pathological cellular response in cancer is frequently associated with amplification and overexpression of the S6K1 gene [3-19].

Current data suggest that most effects of S6K1 are mediated by the major $\mathrm{p} 70$ and $\mathrm{p} 85$ isoforms that are originated from alternative mRNA translation [1]. Little attention, however, has been paid

(C) 2019 I. V. Zaiets et al.; Published by the Institute of Molecular Biology and Genetics, NAS of Ukraine on behalf of Biopolymers and Cell. This is an Open Access article distributed under the terms of the Creative Commons Attribution License (http://creativecommons.org/licenses/by/4.0/), which permits unrestricted reuse, distribution, and reproduction in any medium, provided the original work is properly cited 
to studying the other isoforms. Recent data demonstrate the ability of short S6K1 isoforms to initiate tumorigenesis [20,21], thus underscoring important roles for these isoforms in cancer. Additionally, an evidence exists for the p60S6K1 protein isoform [22]. It was assumed that this isoform originates from an alternative translation event [22]. Moreover,our recent work has confirmed such an assumption [23]. On the other hand, the analysis of current nucleic acid databases has revealed an additional S6K1 splice variant (NM_001272044.1, RefSeq, NCBI) discovered by NEDO human cDNA sequencing project [unpublished data] that presumably could be translated to the p60-S6K1 protein.

The main task of the current study was to confirm the existence of mRNA coding for the p60 isoform of S6K1 and to estimate its expression in various cell lines. Initially, we used RTPCR to identify the p60-S6K1 mRNA in breast cancer cell line MCF-7. After that, DNA sequencing of the PCR product confirmed the identity of the p60-S6K1 transcript which contains an insertion (we called exon 1a) arising from intron 1. To evaluate the expression levels of the p60-S6K1 mRNA in cell lines we also applied RT-PCR. The obtained data revealed heterogeneous expression of the p60-S6K1 mRNA in the studied cell lines, and this expression did not correlate with the expression of total S6K1 mRNA. Addtionally, we compared the levels of p60-S6K1 mRNA and protein expression, demonstrating the absence of correlation between them.

\section{Materials and Methods}

Cell culture. HEK-293, MCF-7 and HeLa, cell cultures were maintained in Dulbecco's modified Eagle medium (DMEM) (Gibco) supplemented with $10 \%$ fetal bovine serum (Gibco),
100 units $/ \mathrm{ml}$ penicillin, $100 \mu \mathrm{g} / \mathrm{ml}$ streptomycin, and $2 \mathrm{mM}$ glutamine. Jurkat and U-937, and HepG2, U-373 and U-87 cell lines were cultured in RPMI-1640 (HyClone) and Eagle's minimum essential medium (EMEM) (Gibco), respectively, containing supplements listed above. All the cells used in this study were grown in 6-cm cell culture dishes until they reached $90 \%$ confluency and lysed for subsequent total RNA isolation. Each cell culture was maintained in a $5 \% \mathrm{CO}_{2}$ incubator at $37^{\circ} \mathrm{C}$.

Oligonucleotides. For PCR detection of the p60-S6K1 transcript and subsequent sequencing of the detected fragment following primers were used: forward - TTCTGTCGGGAGTAGCACTG (encompasses the p60-S6K1 transcript specific insertion), reverse - GTGCTGTGGATTGGTGGAGT (against the exon 9 of the primary S6K1 transcript) with the resulted PCR product size of $787 \mathrm{bp}$. For the evaluation of p60-S6K1, total S6K1 and $\beta$-actin mRNA expression in a subset of cell lines by RT-PCR following primers were used: 1) p60-S6K1: forward - TTCTGTCGGGAGTAGCACTG (the same oligonucleotide as for sequencing), reverse - GTGCTGTGGATTGGTGGAGT (against the exon 3 of the primary S6K1 transcript) with the resulted PCR product size of 257 bp. 2) Total S6K1 (exon 2-4): forward GACCATATGAACTTGGCATGG (against the exon 2 of the primary S6K1 transcript), reverse - TCCCAGTATTTGCTCCTGTTAC (against the exon 4 of the primary S6K1 transcript) with the resulted PCR product size of 174 bp. 3) Total S6K1 (exon 14-15): forward CACCTCGAAGATTTATTGGCA (against the exon 14 of the primary S6K1 transcript), reverse - GTGCTCTGGCCGTTTGG (against the exon 15 of the primary S6K1 transcript) 
with the resulted PCR product size of $260 \mathrm{bp}$. 4) Total S6K1 (full-length): forward AGACAGGGAAGCTGAGGACA (against the exon 1 of the primary S6K1 transcript), reverse - GTGCTCTGGCCGTTTGG (against the exon 15 of the primary S6K1 transcript) with the resulted PCR product size of $1510 \mathrm{bp}$. 5) $\beta$-actin: forward - GGACTTCGAGCAAGAGAT, reverse - AGCACTGTGTTGGCGTAC with the resulted PCR product size of $234 \mathrm{bp}$.

$R T-P C R$. Total RNA was extracted and purified from cell lines using GeneJET RNA Purification Kit (\#K0503, Thermo Scientific). After extraction $1 \mu \mathrm{g}$ of total RNA was treated with DNase I (\#EN0525, Thermo Scientific) and further used to synthesize the first cDNA strand with High-Capacity cDNA Reverse Transcription Kit (\#4374966, Applied Biosystems). All procedures were performed according to manufacturer's instructions. PCR was performed on 1/15 (1.5 $\mu \mathrm{l})$ of cDNA in $25 \mu \mathrm{l}$ of total reaction volume containing $0.2 \mathrm{mM}$ dNTP mix, 10X DreamTaq Buffer (\#EP0701, Thermo Scientific), $0.5 \mu \mathrm{M}$ of each primer and 0.65 units of DreamTaq DNA Polymerase (\#EP0701, Thermo Scientific). For PCR amplification of the full-length p70/p85S6K1 transcript following PCR mixtures were prepared in total volume of $25 \mu \mathrm{l}: 0.2 \mathrm{mM}$ dNTP mix, 5X Phusion HF Buffer (\#F-530S, Thermo Scientific), $3 \%$ DMSO, $0.5 \mu \mathrm{M}$ of each primer and Phusion High-Fidelity DNA Polymerase (\#F-530S, Thermo Scientific). PCR conditions were (i) $95^{\circ} \mathrm{C}$ for $2 \mathrm{~min}$ as initial denaturation followed by 35 cycles of denaturing at $95^{\circ} \mathrm{C}$ for $25 \mathrm{sec}$, annealing at either $55^{\circ} \mathrm{C}$ (for $\beta$-actin) or $57^{\circ} \mathrm{C}$ (for $\mathrm{S} 6 \mathrm{~K} 1$ (exon 2-4, exon 14-15) and p60-S6K1) for $25 \mathrm{sec}$, extension at $72^{\circ} \mathrm{C}$ for $1 \mathrm{~min}$ and a final extension at $72^{\circ} \mathrm{C}$ for $5 \mathrm{~min}$ for PCR amplification with DreamTaq DNA polymerase; (ii) $98^{\circ} \mathrm{C}$ for $1 \mathrm{~min}$, then 35 cycles of $98^{\circ} \mathrm{C}$ for $10 \mathrm{sec}, 62^{\circ} \mathrm{C}$ for $25 \mathrm{sec}$ (for full-length p70/ p85-S6K1) and $72^{\circ} \mathrm{C}$ for $1 \mathrm{~min}$, followed by 5 min at $72^{\circ} \mathrm{C}$ for PCR amplification with Phusion DNA polymerase. Resulting PCR products were resolved on 1-2\% agarose gel.

Immunoblotting. Whole-cell lysates were prepared by suspending cells in lysis buffer (25 mM Tris-HCl, pH 7.5, $150 \mathrm{mM} \mathrm{NaCl,}$ $1 \mathrm{mM}$ EDTA, $0.5 \%$ Triton $\mathrm{X}-100,5 \%$ glycerol, $1 \mathrm{mM}$ Na3VO4, $2.5 \mathrm{mM} \mathrm{Na}$ pyrophosphate, $1 \mathrm{mM} \beta$-glycerophosphate supplemented with a cOmplete EDTA-free protease inhibitor cocktail tablet (Roche) and phosphatase inhibitors (Sigma-Aldrich)) with subsequent centrifugation at $12,000 \mathrm{~g}$ for $10 \mathrm{~min}$ to obtain lysates cleared of insoluble material. The protein content of cleared lysates was measured with the Coomassie Protein Assay Reagent (\#1856209, Thermo Scientific). Samples were resolved by $10 \%$ SDS-PAGE and transferred to a polyvinylidene difluoride (PVDF) membrane (Immobilon $\AA-P$, Millipore). The membrane was further incubated with primary antibodies of appropriate dilutions. The antibody against the S6K1 C-terminus was diluted 1:2500 [24] and dilution for the $\beta$-actin antibody was 1:10000 (clone 13E5, Sigma-Aldrich). Bound antibodies were detected using horseradish peroxidase-conjugated anti-rabbit or anti-mouse antibodies followed by the enhanced chemiluminescence reagent (GE Healthcare). All the secondary antibodies were diluted 1:10000.

\section{Results and Discussion}

Our recent study demonstrated that the p60 isoform of S6K1 can be alternatively trans- 
lated presumably from the common with $\mathrm{p} 85$ / p70 S6K1 transcript via usage of the third in-frame start codon (Fig.1) [23]. Despite the described source of p60-S6K1 translation, the given isoform can be supposedly generated from the alternative S6K1 mRNA splice variant termed as the S6K1 transcript variant 4 (further p60-S6K1 transcript) according to the data of the NCBI Reference Sequence Database (NM_001272044.1, RefSeq, NCBI). A nucleotide sequence for this transcript was derived from the data of NEDO human cDNA sequencing project focused on splicing variants (AK297147.1, GenBank, NCBI) [unpublished data]. This S6K1 transcript contains an insertion between exons 1 and 2 (we called it exon 1a) that bears an in-frame stop codon (Fig. 1). The latter does not allow p70-S6K1 and $\mathrm{p} 85-\mathrm{S} 6 \mathrm{~K} 1$ to be translated causing premature termination of translation. However, the full-length p60-S6K1 isoform can be translated from this transcript (Fig. 1) by utilizing the third in-frame translation start codon located in exon 2. Nevertheless, identity of this transcript, termed p60-S6K1, has not been elucidated, as well as its expression in cells.

To identify the p60-S6K1 mRNA we employed a method of RT-PCR using total RNA from MCF-7 cells as a source of the p60-S6K1 mRNA. For PCR detection one of the primers targeted the p60-S6K1 mRNA-specific exon 1a, whereas another primer was complementary to a region of the exon 9. RT-PCR analysis of MCF-7 total RNA revealed expression of the p60-S6K1 transcript (Fig. 2A). The resulted PCR product was extracted from a gel and subjected to DNA sequencing. The results of sequencing showed that the DNA fragment amplified during PCR corresponded to a nucleotide sequence of the S6K1 transcript variant 4 found in the NCBI Reference Sequence Database (Fig. 2B).

After the identity of p60-S6K1 mRNA was established, we investigated expression of this transcript by RT-PCR in a number of cell lines p60/p70/p85-S6K1
transcript

p60-S6K1 transcript

Constitutive exon 5'/3'-UTR

Alternative exon

$\gg$ Start codon

Q Stop codon
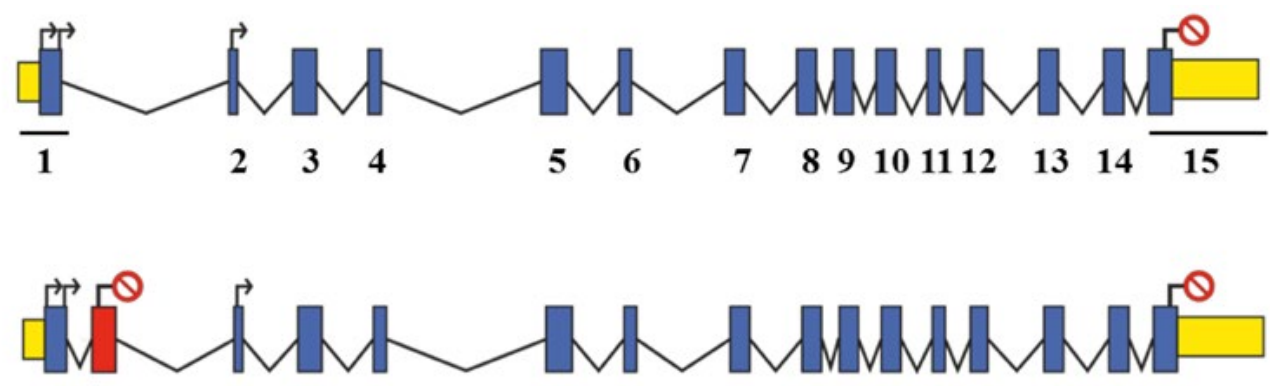

1a

Fig. 1. Schematic demonstration of the p60-S6K1 splice variant relative to the predominant p60/p70/p85-S6K1 transcript. The transcript variant encoding the only p60S6K1 isoform contains an additional exon (designated as 1a) compared to the $\mathrm{p} 60 / \mathrm{p} 70 /$ p85-S6K1 transcript encoding all three isoforms that are translated from corresponding alternative start codons. The 1a exon includes an in-frame stop codon that terminates translation of $\mathrm{p} 70 / \mathrm{p} 85-\mathrm{S} 6 \mathrm{~K} 1$ isoforms, thus forcing $\mathrm{p} 60$-S6K1 transcript to initiate translation only the p60-S6K1 isoform from the third, nearest in-frame start codon. 
$\boldsymbol{A}$

$B$

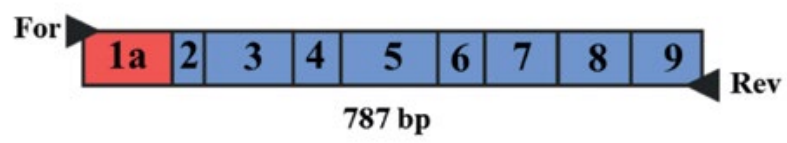

TTCTGTCGGGAGTAGCACTGCCGCTGCTGTTACAGCCACCAGGAG TTTTATTTCGGGAGCAAGGGGGCTCTGCTGCATCTTCCAATCTTC CAGGGGTCAGTTAAATGAAAGCATGGACCATGGGGGAGTTGGACC ATATGAACTTGGCATGGAACATTGTGAGAAATTTGAAATCTCAGA AACTAGTGTGAACAGAGGGCCAGAAAAAATCAGACCAGAATGTTT TGAGCTACTTCGGGTACTTGGTAAAGGGGGCTATGGAAAGGTTTT TCAAGTACGAAAAGTAACAGGAGCAAATACTGGGAAAATATTTGC CATGAAGGTGCTTAAAAAGGCAATGATAGTAAGAAATGCTAAAGA TACAGCTCATACAAAAGCAGAACGGAATATTCTGGAGGAAGTAAA GCATCCCTTCATCGTGGATTTAATTTATGCCTTTCAGACTGGTGG AAAACTCTACCTCATCCTTGAGTATCTCAGTGGAGGAGAACTATT TATGCAGTTAGAAAGAGAGGGAATATTTATGGAAGACACTGCCTG CTTTTACTTGGCAGAAATCTCCATGGCTTTGGGGCATTTACATCA AAAGGGGATCATCTACAGAGACCTGAAGCCGGAGAATATCATGCT TAATCACCAAGGTCATGTGAAACTAACAGACTTTGGACTATGCAA AGAATCTATTCATGATGGAACAGTCACACACACATTTTGTGGAAC AATAGAATACATGGCCCCTGAAATCTTGATGAGAAGTGGCCACAA TCGTGCTGTGGATTGGTGGAGT

Fig. 2. The RPS6KB1 gene gives rise to the transcript variant (p60-S6K1 mRNA) supposedly encoding the p60-S6K1 isoform. A) PCR detection of p60-S6K1 mRNA from MCF-7 cells. For PCR analysis a forward primer was designed to be specific to a region of the inserted exon 1a, whereas a reverse one was complementary to a region of the exon 9. B) A sequenced PCR fragment extracted from the gel represented in A) displays inclusion of the exon 1a (sequence in blue). Primers used for DNA sequencing (sequences in green) were the same as for PCR analysis giving the PCR product of $787 \mathrm{bp}$ in length.

of different origin. Additionally, we analyzed expression of the p60-S6K1 isoform in these cells in comparison with the protein and mRNA expression levels. The data demonstrated heterogeneous expression of the p60-
S6K1 mRNA in different types of cells (Fig. 3A). Moreover, no correlation between the expression levels of the p60-S6K1 mRNA and total S6K1 mRNA was observed. This implies that the p60-S6K1 isoform could play a different role compared to the full-length

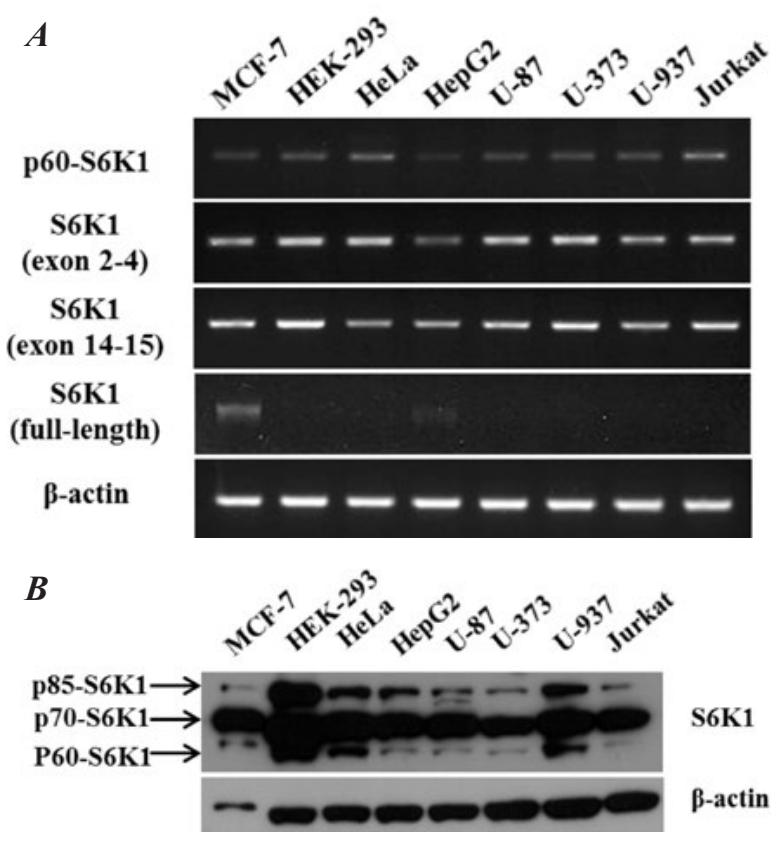

Fig. 3. Expression profile of the p60-S6K1 isoform in a panel of cell lines. A) RT-PCR analysis of p60-S6K1 mRNA expression in different cell lines (MCF-7, HEK293, HeLa, HepG2, U-87, U-373, U-937, Jurkat). A subset of the cell lines was subjected to a total mRNA isolation and subsequent cDNA synthesis. Total cDNA for each cell line was analyzed by PCR using primers specific to p60-S6K1 (top panel), total S6K1 (medium panels) and $\beta$-actin (bottom panel). The resulted PCR products were separated by $2 \%$ agarose gel electrophoresis. B) Western blot analysis of $\mathrm{p} 60-\mathrm{S} 6 \mathrm{~K} 1$ protein expression in the indicated cell lines. Whole-cell lysates were prepared from the cell lines and loaded onto $10 \%$ SDSPAGE $(20 \mu \mathrm{g}$ of each lysate except for $2 \mu \mathrm{g}$ of MCF-7 lysate). Separated S6K1 was blotted against polyclonal C-terminal S6K1 antibodies. $\beta$-actin was used to confirm equal loading of protein in each lane. 
$\mathrm{p} 70 / \mathrm{p} 85-\mathrm{S} 6 \mathrm{~K} 1$ isoforms. To our surprise, however, usage of different primer pairs for detection of total S6K1 mRNA gave different expression profiles. Only a pair of primers producing full-length p60/p70/p85-S6K1 mRNA detected the expression levels which roughly conformed to the protein expression levels shown by immunoblotting, although the efficiency of PCR employing these primers was quite low. However, a question why the use of different S6K1 primers provides varied the results of S6K1 expression remains to be resolved in future studies since it is very important for further quantitative analysis of p60S6K1 expression in cells and tissues.

The results also showed that p60-S6K1 mRNA expression levels do not correlate with those of the p60-S6K1 protein (Fig. 3). The absence of correlation between p60-S6K1 mRNA and protein expression may be accounted for a mechanism of p60-S6K1 generation, since this isoform can also be initiated from the common $\mathrm{p} 60 / \mathrm{p} 70 / \mathrm{p} 85-\mathrm{S} 6 \mathrm{~K} 1$ transcript. Therefore, the ability of a cell to produce the p60-S6K1 isoform using alternative pathways might be responsible for such a difference between the p60-S6K1 mRNA and protein levels. Unfortunately, we could not estimate the contribution of the p60-S6K1 transcript expression in the protein level of the p60-S6K1 isoform applying the siRNA technology, since the p60S6K1-specific insertion represented a poor target sequence for RNAi.

In conclusion, we provided a new evidence for the existence of the novel S6K1 transcript, referred to as the p60-S6K1 transcript suggesting existence of at least two alternative modes in the p60S6K 1 expression. The identified transcript displays a differential pattern of expression in different cell types. Yet, the expression of the p60-S6K1 mRNA does not correlate with the total S6K1 mRNA indicating that the former could play a distinct and independent role in cellular physiology and S6K1related diseases.

This work was funded by the State Budget Program «Support for the Development of Priority Areas of Scientific Research» (Code: 6541230).

\section{REFERENCES}

1. Fenton TR, Gout IT. Functions and regulation of the $70 \mathrm{kDa}$ ribosomal S6 kinases. Int J Biochem Cell Biol. 2011;43(1):47-59.

2. Zoncu R, Efeyan A, Sabatini DM. mTOR: from growth signal integration to cancer, diabetes and ageing. Nat Rev Mol Cell Biol. 2011;12(1):21-35.

3. Couch FJ, Wang XY, Wu GJ, Qian J, Jenkins RB, James $C D$. Localization of PS6K to chromosomal region $17 \mathrm{q} 23$ and determination of its amplification in breast cancer. Cancer Res. 1999;59(7):1408-11.

4. Bärlund M, Monni O, Kononen J, Cornelison R, Torhorst J, Sauter G, Kallioniemi OLLI-P, Kallioniemi A. Multiple genes at 17q23 undergo amplification and overexpression in breast cancer. Cancer Res. 2000;60(19):5340-4.

5. Bärlund M, Forozan F, Kononen J, Bubendorf L, Chen Y, Bittner ML, Torhorst J, Haas P, Bucher C, Sauter G, Kallioniemi OP, Kallioniemi A. Detecting activation of ribosomal protein S6 kinase by complementary DNA and tissue microarray analysis. J Natl Cancer Inst. 2000;92(15):1252-9.

6. Miyakawa M, Tsushima T, Murakami H, Wakai K, Isozaki $O$, Takano $K$. Increased expression of phosphorylated p70S6 kinase and Akt in papillary thyroid cancer tissues. Endocr J. 2003;50(1):77-83.

7. Lytvyn DI, Dudchenko TM, Lyzogubov VV, Usenko VS, Nespryadko SV, Vinnitskaya AB, Vorobyova LI, Pal'chevskiy SS, Filonenko VV, Pogrebnoy $P V$. Expression of $\alpha$ - and $\beta$-isoforms of p70S6 
kinase in human endometrial tumors. Exp Oncol. 2003;25(4):274-8.

8. Lyzogubov VV, Usenko VS, Khojaenko YS, Lytvyn DI, Soldatkina MA, Rodnin NV, Filonenko VV, Pogribniy $P V$. Immunohistochemical analysis of p70S6 kinase $\alpha$ in human thyroid tissue upon pathology. Exp Oncol. 2003;25(4):304-6.

9. Lyzogubov VV, Lytvyn DI, Dudchenko TM, Lubchenko NV, Pogrybniy PV, Nespryadko SV, Vinnitska AB, Usenko VS, Gout IT, Filonenko VV. Immunohistochemical analysis of S6K1 and S6K2 expression in endometrial adenocarcinomas. Exp Oncol. 2004;26(4):287-93.

10. van der Hage JA, van den Broek LJ, Legrand C, Clahsen PC, Bosch CJ, Robanus-Maandag EC, van de Velde CJ, van de Vijver MJ. Overexpression of P70 S6 kinase protein is associated with increased risk of locoregional recurrence in node-negative premenopausal early breast cancer patients. $\mathrm{Br} J$ Cancer. 2004;90(8):1543-50.

11. Lyzogubov V, Khozhaenko Y, Usenko V, Antonjuk S, Ovcharenko G, Tikhonkova I, Filonenko V. Immunohistochemical analysis of Ki-67, PCNA and S6K1/2 expression in human breast cancer. Exp Oncol. 2005;27(2):141-4.

12. Pantuck AJ, Seligson DB, Klatte T, Yu H, Leppert JT, Moore L, O'Toole T, Gibbons J, Belldegrun AS, Figlin RA. Prognostic relevance of the mTOR pathway in renal cell carcinoma: implications for molecular patient selection for targeted therapy. Cancer. 2007;109(11):2257-67.

13. Noh WC, Kim YH, Kim MS, Koh JS, Kim HA, Moon NM, Paik NS. Activation of the mTOR signaling pathway in breast cancer and its correlation with the clinicopathologic variables. Breast Cancer Res Treat. 2008;110(3):477-83.

14. Zhou L, Huang Y, Li J, Wang Z. The mTOR pathway is associated with the poor prognosis of human hepatocellular carcinoma. Med Oncol. 2010;27(2):255-61.

15. Hiramatsu $M$, Ninomiya $H$, Inamura K, Nomura K, Takeuchi K, Satoh Y, Okumura S, Nakagawa K, Yamori T, Matsuura M, Morikawa T, Ishikawa Y. Activation status of receptor tyrosine kinase downstream pathways in primary lung adenocarcinoma with reference of KRAS and EGFR mutations. Lung Cancer. 2010;70(1):94-102.

16. Pérez-Tenorio G, Karlsson E, Waltersson MA, Olsson B, Holmlund B, Nordenskjöld B, Fornander T, Skoog L, Stål O. Clinical potential of the mTOR targets S6K1 and S6K2 in breast cancer. Breast Cancer Res Treat. 2011;128(3):713-23.

17. Li PD, Zhang WJ, Zhang MY, Yuan LJ, Cha YL, Ying $X F, W u G$, Wang $H Y$. Overexpression of RPS6KB1 predicts worse prognosis in primary HCC patients. Med Oncol. 2012;29(5):3070-6.

18. Karlsson E, Magić I, Bostner J, Dyrager C, Lysholm F, Hallbeck AL, Stål O, Lundström P. Revealing Different Roles of the mTOR-Targets S6K1 and S6K2 in Breast Cancer by Expression Profiling and Structural Analysis. PLoS One. 2015;10(12): e0145013.

19. Pópulo H, Soares P, Faustino A, Rocha AS, Silva P, Azevedo F, Lopes JM. mTOR pathway activation in cutaneous melanoma is associated with poorer prognosis characteristics. Pigment Cell Melanoma Res. 2011;24(1):254-7.

20. Ben-Hur V, Denichenko P, Siegfried Z, Maimon A, Krainer A, Davidson B, Karni R. S6K1 alternative splicing modulates its oncogenic activity and regulates mTORC1. Cell Rep. 2013;3(1):103-15.

21. Karni R, de Stanchina E, Lowe $S W$, Sinha R, Mu D, Krainer AR. The gene encoding the splicing factor SF2/ASF is a proto-oncogene. Nat Struct Mol Biol. 2007;14(3):185-93.

22. Kim D, Akcakanat A, Singh G, Sharma C, MericBernstam $F$. Regulation and localization of ribosomal protein S6 kinase 1 isoforms. Growth Factors. 2009;27(1):12-21.

23. Zaiets IV, Sivchenko AS, Khoruzhenko AI, Savinska LO, Filonenko $V V$. The p60-S6K1 isoform of ribosomal protein $\mathrm{S} 6$ kinase 1 is a product of alternative mRNA translation. Ukr Biochem $J$. 2018;90(4):25-35.

24. Savinska LO, Kijamova RG, Pogrebnoy PV, Ovcharenko GV, Gout IT, Filonenko VV. Comparative characterization of S6 kinase $\alpha$ and $\beta$ isoforms expression in mammalian tissues. Biopolym Cell. 2001;17(5):374-9. 


\section{Ідентифікація нового сплайсового варіанту S6K1, який кодує ізоформу р60-S6K1.}

І. В. Заєць, В. В. Голяр, В. В. Філоненко

Мета. 3'ясувати можливість існування сплайсової мРНК кінази S6К1 специфічної виключно для р60S6К1 ізоформи. Методи. ЗТ-ПЛР, ДНК секвенування, Вестерн-блоттинг. Результати. ЗТ-ПЛР аналіз тотальної РНК, виділеної із клітин лінії МСF-7, з наступним секвенуванням ДНК виявив новий сплайсовий варіант мРНК S6K1, що містить додатковий екзон 1a i кодує лише p60 ізоформу S6K1. Для оцінки рівня експресії p60-S6K1 мРНК та білку було застосовано ЗТ-ПЛР та вестерн-блот. Результати вказують на гетерогенну експресію транскрипту p60-S6K1, що не корелює ні з експресією загальної S6K1 мРНК, ні з білковим вмістом p60-S6K1 у досліджуваних клітинних лініях. Висновки. Надано докази існування нової сплайсової мРНК S6K1, яка кодує ізоформу p60-S6K1, що свідчить про існування в клітині двох незалежних шляхів експресії p60-S6K1, а саме альтернативну трансляцію спільної для головних S6K1 ізоформ мРНК та/чи трансляцію нової специфічної лише для p60-S6K1 сплайсової мРНК. Оскільки рівень експресії p60-S6K1 транскрипту в різних клітинних лініях не корелює із експресією загальної мРНК S6K1, цілком можливо, що p60-S6K1 ізоформа може відігравати відмінну від інших S6K1 ізоформ роль у клітинній фізіології, а також при розвитку патологій, які пов'язані із S6K1.

К л ю ч о в і с л о в а: p60-S6K1 транскрипт, альтернативний сплайсинг, експресія генів.

\section{Идентификация нового сплайсового варианта S6K1, который кодирует изоформу р60-S6K1.}

И. В. Заец, В. В. Голяр, В. В. Филоненко

Цель. Выяснить возможность существования сплайсинговой мРНК киназы S6К1 специфической исключительно для р60-S6К1 изоформы. Методы. ОТ-ПЦР, ДНК секвенирование, Вестерн-блоттинг. Результаты. ОТ-ПЦР анализ тотальной РНК, выделенной из клеток линии MCF-7, с последующим секвенированием ДНК выявил новый сплайсовый вариант S6K1, содержит дополнительній екзон 1а и кодирует только изоформу p60-S6K1. Далее были использованы OT-ПЦР и вестерн-блоттинг для оценки уровней р60-S6K1 мРНК и белка. Результаты показали гетерогенную экспрессию транскрипта р60S6K1, экспрессия которого не коррелировала ни с тотальной S6K1 мРНК, ни с белковым содержанием p60-S6K1 в исследуемых клеточных линиях. Выводы. Предоставлены доказательства существования нового сплайсового варианта S6K1, который кодирует изоформу p60-S6K1, что указывает на существование в клетке двух независимых путей експрессии р60-S6K1 изоформы, а именно альтернативную трансляцию общей для основных изоформ мРНК и/или трансляцию новой специфичной лишь для p60-S6K1 сплайсовой мРНК. Поскольку уровень экспрессии p60-S6K1 транскрипта в различных клеточных линиях не коррелируют с экспрессией тотальной S6K1 мРНК, можна предположить, что p60-S6K1 изоформа может играть отличную то других S6K1 изоформ роль в клеточной физиологии, а также при развитии патологий, которые связаны с S6K1.

К л юч е в ы е с л о в а: p60-S6K1 транскрипт, альтернативный сплайсинг, экспрессия генов.

Received 25.11.2018 